\title{
Root Initiation in Aerial Offshoots of Date Palm (Phoenix dactylifera) by Exogenous Application of Auxins
}

\author{
Muhammad Tayyab ${ }^{1}$, Saeed Ahmad ${ }^{1}$, Malik Mohsin Abbas ${ }^{2}$, Muhammad Ikhlaq Khan ${ }^{3}$, Komal \\ Aslam $^{4,5 *}$, Maryam Nasir ${ }^{4}$, Hira Faiz ${ }^{4}$ \\ ${ }^{1}$ University of Agriculture Faisalabad \\ ${ }^{2}$ Horticultural research institute, Ayub agricultural research institute Faisalabad \\ ${ }^{3}$ Horticultural research station, Bahawalpur \\ ${ }^{4}$ Horticultural research institute, Ayub agricultural research institute Faisalabad \\ ${ }^{5}$ Horticultural Research Institute, AARI, Jhang road, Faisalabad, Pakistan \\ *Corresponding Authors Komal Aslam komalaslam2703@gmail.com \\ Article Received 14-06-2021, Article Revised 03-07-2021, Article Accepted 03-08-2021 \\ Abstract
}

Date palm (Phoenix dactylifera) is commercially propagated through offshoots. Along with this rooted offshoot the tree also produces aerial offshoots, which are rootless and die after plantation. In this study attempts have been made to evaluate the effect of auxins on the root initiation of the aerial offshoots of date palm cv. Hillawi. Therefore, an experiment was conducted to evaluate the effect of IAA (500 ppm), NAA (500 ppm), alone and in combination on root initiation in aerial offshoots of date palm cv. Hillawi. The auxins were applied to the aerial shoots by injection method. The experiment was laid out according to Randomized Complete Block Design (RCBD) with four treatments (Control, 500pmm IAA, 500ppm NAA and 500ppm IAA+NAA) and each treatment was replicated thrice. Injection method was used to apply the hormones and after the application of auxins the base of each offshoot was wrapped carefully with gunny bags having pinewood shaving as rooting media. After 40 days of supplication, offshoots were detached, and parameters were collected. Data indicated that NAA ( 500ppm gave highest rooting percentage (24.5\%), total number of roots per offshoot (82.33) and total weight of roots per offshoots $(607.4 \mathrm{~g})$ as compared to other treatments. Similarly, a greater number of smaller roots $($ dia $<0.5 \mathrm{~cm})$ was also achieved in offshoots treated with $500 \mathrm{ppm}$ NAA. Hence, it may be concluded that root initiation was remarkable in NAA alone and in combination with IAA at 500ppm concentration in comparison to other treatments.

Keywords: Phoenix dactylifera, root initiation, offshoot, auxins, Indole acetic acid, Naphthalene acetic acid

\section{Introduction}

Data palm is one of the very old tropical and sub-tropical fruit crop. It was originated from countries of Persian Gulf i.e. Iran, Iraq, Saudi Arabia and North Africa. In Indo-Pak subcontinent the date was introduced by the efforts of Alexander, the Arab Conquerors (Pureseglove, 1972). From the ancient times, date palm has remained a vital crop in the desert regions of Arabian countries and has created the basis of survival for many prehistoric nomads (Muhammad et al., 1983). Date fruit is consumed throughout the world as food due to its high nutritional value with special reference to calories and important minerals. Dates are affluent in certain nutrients and supply a good source of rapid energy due to their high percentage of carbohydrate contents. (Al-Farsi et al., 2005; Myhara et al., 1999). Due to high content of potassium and low sodium it has great therapeutic value for over sensitive persons who need low sodium in diet. Date is fourth major fruit of Pakistan and cultivated over an area of 984.15 thousand ha from which annual fruit production is 540.61 thousand tonnes (FAO, 2019). Punjab province shares $6.9 \%$ of total production. Many cultivars i.e. Hillawi, Khudrawi, Mekran, Shamran, Dhakki, Aseel, Kur, Shakri, Kupra,Zahidi, Haleeni, Khurma etc are being grown in Punjab and are consumed at different stages 
of maturity. Among them Hillawi is most popular variety as it is consumed at dokka stage. At this stage Hillawi is crispy, sweet and edible. Moreover, it is also sold at higher rate because it ripens earlier (before onset of Monsoon season) compared to other varieties. The date palm is commonly propagated by offshoots which are of two types i.e. ground and aerial offshoots. Offshoots are developed by initiation of vegetative buds under or over the ground surface. The orchard developed by offshoots is identical to parent plants. For variety development, dates are also propagated through seeds. The developed seedlings are approximately $50 \%$ each male and female Vegetative propagation is also carried by tissue culture techniques which are quite expensive, laborious and needs special expertise. So, the commercial method of propagation is via suckers/offshoots (AlManzouri et al., 2007). Depending upon the variety and climatic conditions every date palm plant produces $15-20$ suckers during their initial 5-7 years and once the offshoots are removed the plant do not produces the offshoots. Among these offshoots $60-65 \%$ at ground level, are aerial. Aerial offshoots are usually the neglected by the farmers as they have a smaller number of roots as compared to ground offshoots but these offshoots can be planted after development of roots (AlManzouri et al., 2007 and Zirari et al., 2010). Offshoots of prime quality commercial cultivars have always been hard to root, and their endurance is also low (VIJ et al., 1977). Aerial offshoots can be planted after development of roots by different root promoting substances that can enhance rooting but lack appropriate amount of root promoting hormone i.e. auxins (Hartmann et $a l .$, 2011). Therefore, the addition of auxins to these offshoots greatly improves rooting (Raz, 1959). Prior studies indicates that if aerial offshoots provided with proper rooting substrate in addition to rooting hormone, healthy roots can be developed, as (Rashid and Al.Obeed 2005) studied root initiation in aerial offshoots by air layering of four date cultivars using $0.8 \%$ NAA as rooting hormone. Rashid and Al-Obeed (2005) studied effect of NAA treatment on root initiation in aerial offshoots of four date palm cultivars (Khalas, Seigh, Succary and Seleg). Results indicated that after 6 months of application Khalas and Seighdeveloped good root initiation as compared to other two. Results also showed that cultivars vary in number of small diameter roots $(<0.5 \mathrm{~cm})$, number of large diameter roots $(>0.5 \mathrm{~cm})$, mean root length, weight of large and smaller roots. Date palm offshoots (Siwi and Omhaat cultivars) when treated with different concentration (2000, 3000, $4000 \mathrm{ppm})$ of IBA and NAA gave good offshoot growth rate, number and length of roots, number of new palm fronds and percentage of dry matter in leaves in comparison to control (Haseeb et al., 2016). The aim of this study was to develop such technique/treatment which stimulate the aerial offshoots to form a strong root mass with use of different synthetic auxins (1-Naphthaleneacetic acid and 1-Naphthaleneacetic acid) This will increase number of available offshoots of excellent and commercially desirable palm cultivars for large scale plantation; farmers will be able to increase their income as an additional source. This will ultimately uplift country's datepalm industry to gain more profit and quality production

\section{Material and method}

Forty eight healthy, disease free and uniform sized aerial offshoots of date palm Cv. Hillawi were selected as planting material. Experiment was carried out at Date Palm research Sub Station, Jhang during the year 2009-2010.Treatments were carried out viz., Indole acetic acid (IAA @ 500 ppm), naphthalene acetic acid (NAA @ 500 ppm) and NAA+IAA (500 ppm each). The formulations were made according to Hartman and Kester (1969). Five years old plants were pruned and dried fronds whorls were removed from base with sharp and sterilized steel saw. The basement of medium sized offshoots (weighing $5-11 \mathrm{~kg}$ ) was treated with Thiopenete methyl @ 3 grams per litre of water to avoid fungus attack. Sharp holes of $0.5 \mathrm{~cm}$ diameter and 1 inch 
deep were drilled in the basement of each offshoot for injecting auxins. The holes were than plugged with sterilized cotton tightly. Formulations of NAA, IAA and NAA+IAA were then injected into these holes @ $10 \mathrm{ml}$ per offshoot with the help of B.D. syringes $(15 \mathrm{cc})$. Pine wood shaving dipped in water, were used as rooting medium. Media was wrapped in gunny bag pieces ( 1.5 feet wide \& 2 feet long). Five to seven $\mathrm{kg}$ rooting media were placed in each piece and then adjusted properly around the basement of offshoots to make sure that whole treated area got covered. After 40 days, offshoots were detached from mother plant with help of sharp, disinfected chisel. Cultural practices followed were same in all treatments. After removal, all roots were categorized into two pars i.e. smaller diameter roots $(<0.5 \mathrm{~cm})$ and larger diameters roots $(>0.5 \mathrm{~cm})$. The following parameters i.e. total number of roots per offshoot, number of large diameter roots, number of small diameter roots, number of root primodal per offshoot, average number of root hairs per root, average length of large diameter roots, average length of small diameter roots, length of longest root per offshoot, total weight of all roots per offshoot and rooting percentage for all the treatments were collected after 40 days of treatment application (Tayyab, 2011).

The experiment was laid out according to Randomized Complete Block Design (RCBD) with four treatments which were replicated three times. The experimental data was analysed for variance (ANOVA) using MSTAT-C. (Steel et al., 1997). The significant differences among treatment results were calculated and compared by subjecting mean values to Least Significant Difference test (LSD) at $P \leq 0.05$.

\section{Results and discussion:}

Total number of roots per offshoot:

Root initiation success in aerial offshoots of date palm is directly related to types of growth regulator applied and their method of application. Results showed that applied treatment had significant effect on total number of roots in aerial offshoot. Mean values revealed that maximum number of roots per offshoot (82.33) were recorded with 500 ppm of NAA (Fig. 1). Minimum number of roots per offshoot was recorded for control treatment (Fig. 1). The results are in line with the findings of the Afzal et al. (2011), who studied root induction in aerial offshoots of date palm cv. Hillawi where IBA @ 3000 ppm was injected in the offshoot for induction of roots. El-Hodairi et al. (1992) reported root initiation by NAA at 50 and 100 $\mathrm{mg} / \mathrm{l}$ but did not find any positive effect of IAA and IBA each at the same levels. Findings of this study is also supported by AlMana et al. (1996), who observed highest number of roots in aerial and ground offshoots of date palm by applying NAA@50ppm in comparison to control. It is also reported that most palm showed highest rooting percentage in warmer months (Pittenger et al., 2000). Auxins (IAA \& NAA) when applied on shoots of date palm showed positive significant effect on number of roots (Khan et al., 1983). In another study NAA significantly enhanced number of roots (10.16) per offshoot followed by IBA and IAA (El-Kosary et al., 2005). The results of Krack et al. (1981) revealed that after 40 days of application of NAA, the endogenous level of hormone was decreased as compared to other Auxins, which indicate that NAA is much interact in root initiation process and improves number of roots significantly. NAA is well known for its influence on root initiation and boosting of root initials in hard to root woody species such as date palm. Thus, results of this study are clear that application of naa at lower doses by injection method in warmer months of summer have much more significant effect on rooting as compared to other levels, method of application (dusting/dipping) and other seasons. 


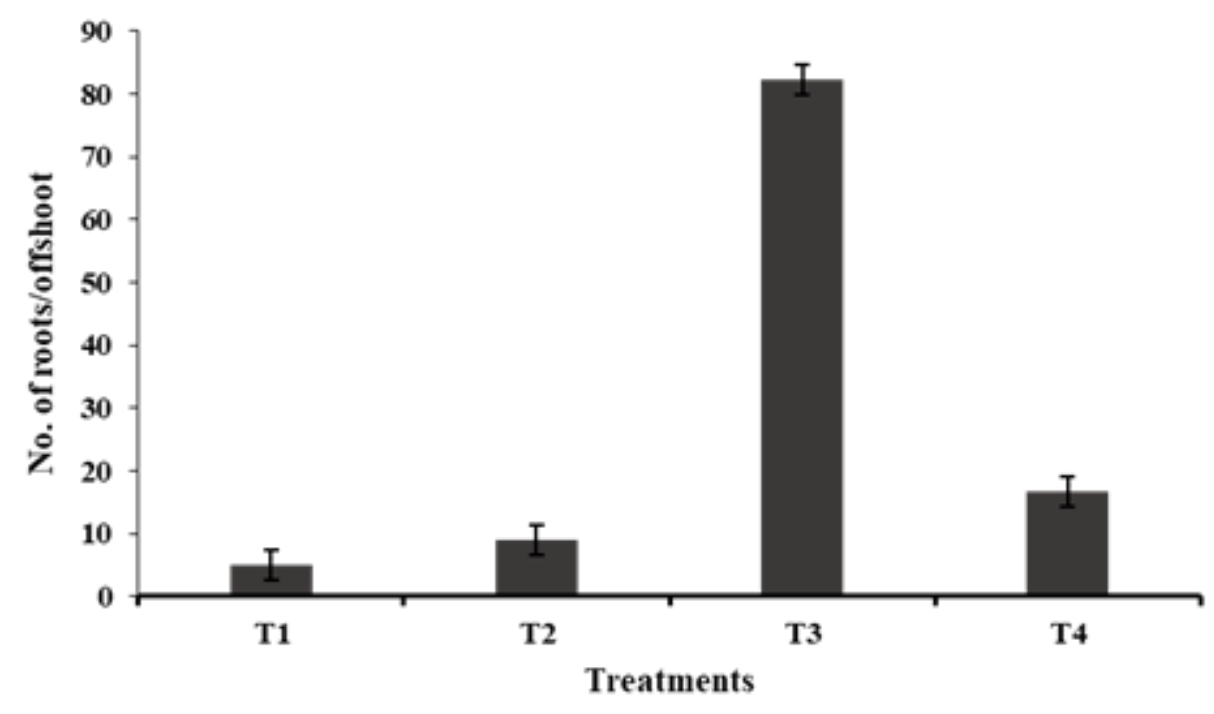

Fig. 1: Total number of roots per offshoot as affected by rooting hormone application. $T_{1}=$ control, $_{2}=$ 500ppm IAA, T $_{3}=500 \mathrm{ppm}$ NAA \& $\mathrm{T}_{4}=500 \mathrm{ppm}$ IAA+NAA.

Number of large diameter roots $(>0.5 \mathrm{~cm})$ per offshoot: Non-significant effect of treatment application was noted in number of large diameter roots (Fig. 2) of date palm cv. Hillawi. Non-significant effect of IAA alone and in combination with NAA may be due to oxidative degradation of IAA by IAA oxidase enzyme which naturally found in plant tissues (Hess., 1968; Donoho et al., 1962). This type of root inhibitor is found in large quantity in weaker offshoots. It is concluded that IAA can be used in healthy shoots alone or in combination with some carbohydrates which can check the inhibitory activities of oxidases.Our findings are in line with ElHodairi et al. (1992), who reported that application of NAA @ 100ppm resulted in higher number of large diameter roots as compared to control. Root initiation of date palm at $1 \mathrm{mg} / \mathrm{L}$ of NAA gave good number of primary adventitious roots (Kheriallah and Bader, 2007).

Number of small diameter roots $(<0.5 \mathrm{~cm})$ per offshoot: Data regarding number of small diameter roots found significant with respect to treatment. Maximum number of small diameter roots (65.14) was recorded from offshoots treated with 500ppm NAA. Minimum number of small diameter roots (1) were found in control treatment (Fig. 2). Small diameter roots are very important in propagating offshoots as they considered to increase endurance rate of newly rooted/to root plants. These roots improve absorption ability thus, a greater number of small diameter roots ensure survival \%age of offshoots (El-Hamady et al., 1992). Our findings are in line with the results of Rashid and Al-Obeed (2005), they stated that application of NAA increases the number of small diameter roots in Seieg and Khalascvs. of date palm. El-Hodairi et al. (1992) also found that application of auxin in form of NAA@100ppm significantly increased the number of small diameter roots in Taaghyaat variety of date palm 


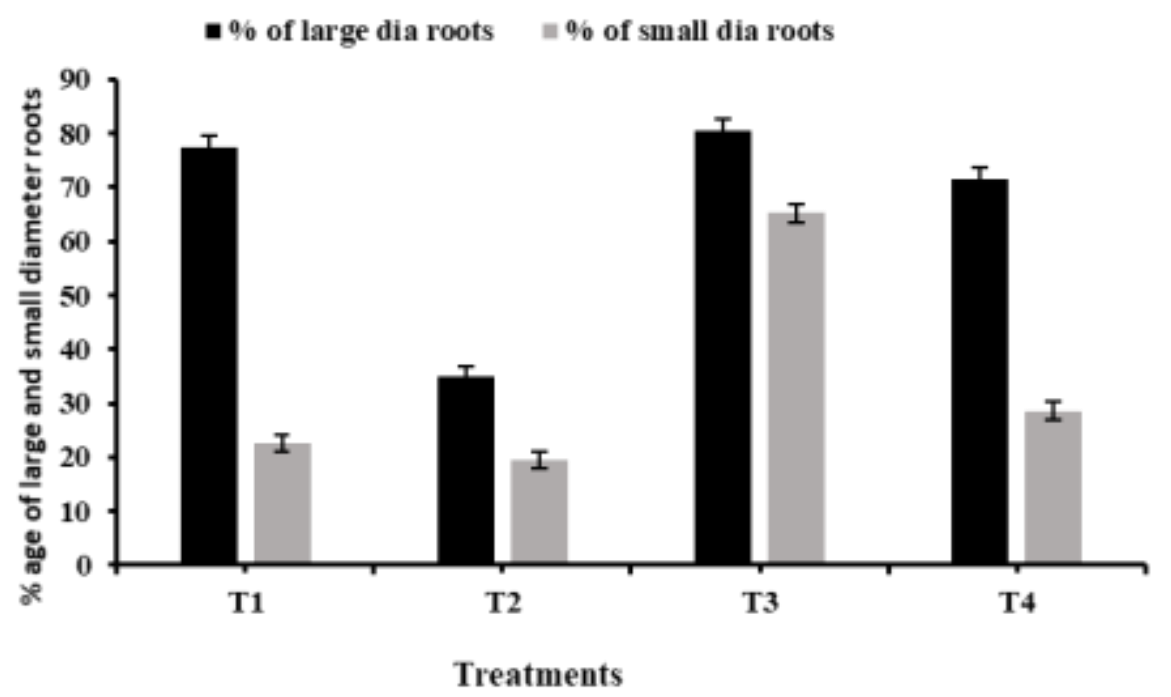

Fig. 2: Percentage of large diameter roots and small diameter roots per offshoot as affected by rooting hormone application. $T_{1}=$ control, $T_{2}=500 \mathrm{ppm}$ IAA, $T_{3}=500 \mathrm{ppm} \mathrm{NAA} \mathrm{\&} T_{4}=500 \mathrm{ppm}$ IAA+NAA.

Number of root primordial per offshoot: Root primordial per offshoot in date palm cv. Hillawi found significantly different in growth regulator treated offshoots when compared with control. Values of treatment means presented in Fig.3 revealed that highest number of root primordial were recorded in NAA treated offshoots (21.63), while lowest in control (5.66). Auxin is widely useful in the vegetative propagation of various plants (Hunt et al., 2010; Husenand
Pal, 2006) and there are many deviations in the range of effectiveness of 1naphthaleneacetic acid (NAA) dosages in different plant species (Yan et al., 2014). Auxins are known for its impact on root initiation in hard to root species such as date palm (Husen and Pal, 2006). Our results are supported by Al-Mana et al. (1996) who observed that application of NAA @ 8\% improves adventitious primary roots and rooting primordial as well.

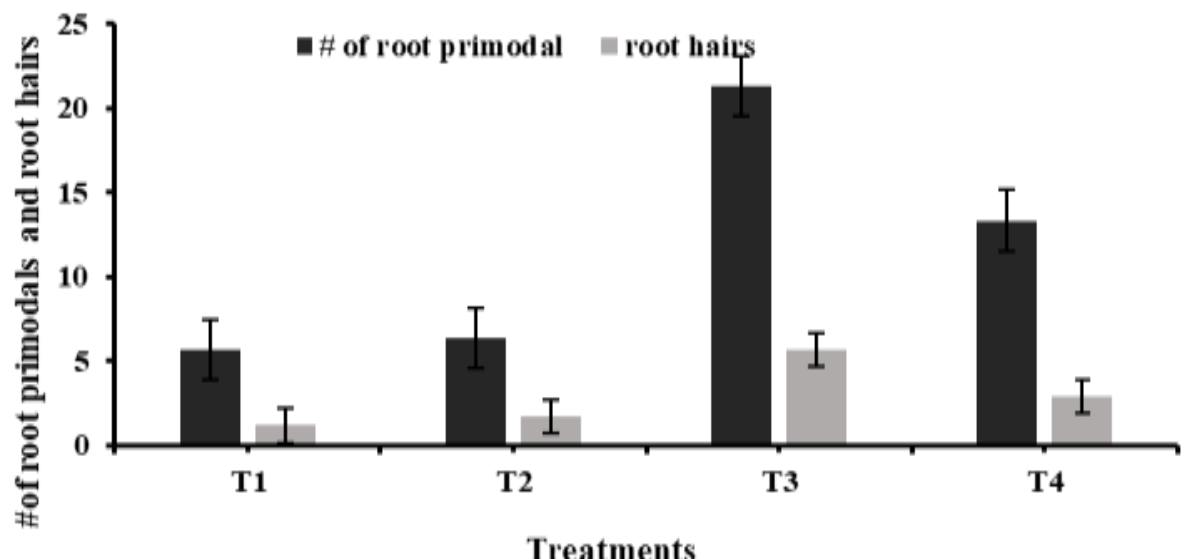

Figure\#3: Number of roots primodal and average number of root hairs per offshoot as affected by rooting hormone application. $T_{1}=$ control, $T_{2}=500 p p m$ IAA, $T_{3}=500 p p m$ NAA \& $T_{4}=500 p p m$ IAA+NAA.

Average number of root hairs: Average number of root hairs per offshoot significantly affected by hormone application.
Mean values are presented in Figure 3 which showed that highest number (5.56) of root hairs were recorded in NAA treated offshoots 
while minimum (1.16) in un-treated (control) which is also at par with the value recorded from IAA treated (1.16) offshoots. Root hairs play key role in absorption capacity of root system therefore large number of root hairs means enhanced survival rate of offshoots. Our results are in line with El-Hodairi et al. (1992) who described that application of NAA @100ppm improved number of root hairs per root, while lower concentration i.e. $50 \mathrm{ppm}$ slightly improve number of root hairs. Al-Mana et al. (1996) observed that offshoots of date palm treated with NAA+50ppm catechol gave highest number of root hairs as compared to control. Rashid and Al-Obeed (2005) also observed same pattern of root hair development and stated that NAA significantly increased number of root hairs in Siege and Khalas cultivars of date palm after six months of hormonal treatments.

Average length of large diameter roots: Application of rooting hormone significantly affected average length of large diameter roots. Mean values showed that maximum value for average length of large diameter roots $(20.35 \mathrm{~cm})$ was obtained from IAA $@ 500 \mathrm{ppm}$ treated roots while minimum $(9.28 \mathrm{~cm})$ in control treatment (Figure 4). Our results are in line with the findings of Papaiah and Muthuswamy (1976). They reported that application of auxin IAA increases the length of primary root, number of roots and also gave highest root initiation percentage. IAA had significant role in cell division and cell elongation of plants (Goldsmith, 1986). Increase in length of large diameter roots in IAA treated offshoots might be due to high rate of cell division and cell elongation during development process of roots which increases length of primary roots while reducing the overall number of roots and root hairs. The behaviour is not favourable for endurance of offshoots of hard to root species like date palm (El-Hamady et al., 1992).

Average length of small diameter roots: Average length of small diameter roots showed that maximum length of small diameter roots was observed in offshoots treated with IAA $(10.617 \mathrm{~cm})$ which is statistically at par with NAA $(10.27 \mathrm{~cm})$ while minimum length of small diameter roots was found in control treatment $(9.28 \mathrm{~cm})$ (Fig. 4). Results can be compared with the observations of El-Hodairi et al. (1992), they stated that the application of NAA increases length of small diameter roots and maximum response was with 100ppm NAA that increases the length of small diameter roots by $88 \%$ in comparison to control. However, the length of small roots decreases with IAA and IBA. Our findings are in contrasts to above mentioned results which may be due to high concentration of IAA i.e. 500ppm which trigger cell elongation and cell division process. Small diameter roots re more helpful in survival of offshoots as they provide site for water and nutrient uptake (El-Hamady et al.,

1992).

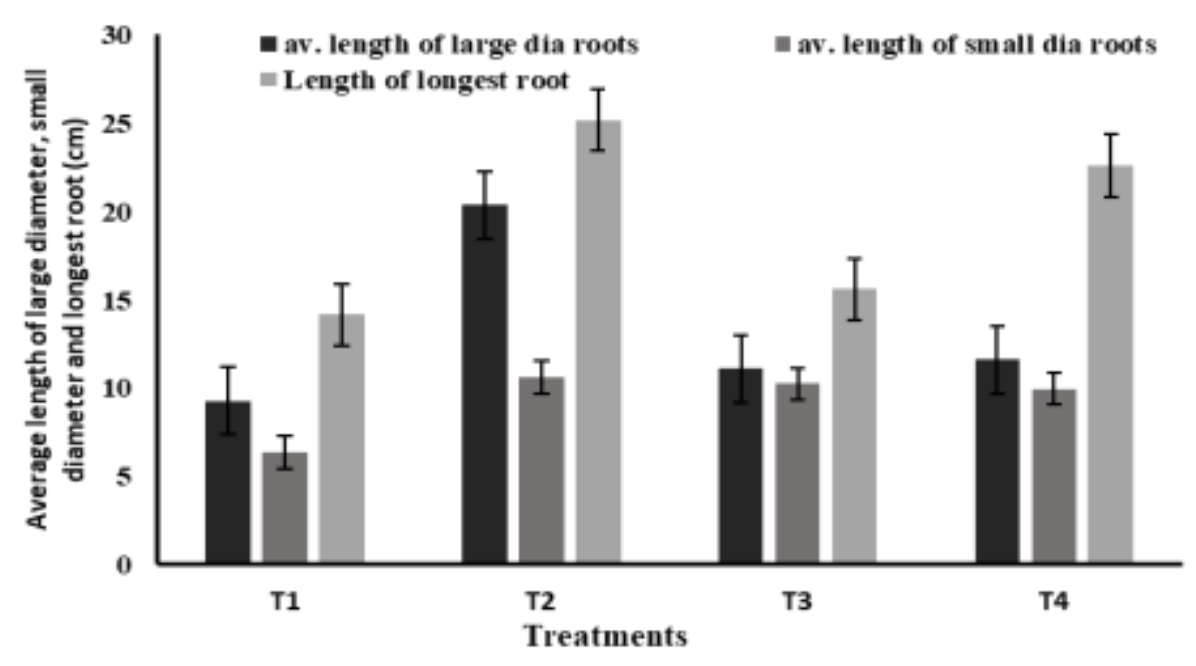


Fig. 4: Average length of large diameter roots, average length of small diameter roots and average length of longest root per offshoot as affected by rooting hormone application. $T_{1}=\operatorname{control}, T_{2}=500 \mathrm{ppm} \mathrm{IAA,} T_{3}=$ 500ppm NAA \& $\mathrm{T}_{4}=500 \mathrm{ppm}$ IAA+NAA.

Length of longest root per offshoot: Length of longest root per offshoot found significant with respect to treatment applied and presented in Fig 4. It is evident that longest root length was observed from IAA injected offshoots followed by combine treatment of IAA and NAA $(22.16 \mathrm{~cm})$. Our results are in line with findings of Al-Mana et al. (1996) who stated that NAA and catechol improved the length of roots in offshoots of date palm and maximum root length was recorded in 25ppm and 50ppm catechol application as compared to control. Further El-Hodairi et al. (1992) reported that IAA and IBA upsurges the length of roots. Khan et al. (1983) observed that auxins like IAA and NAA when applied on offshoots of date palm, gave significant effect on length of roots. So, it is concluded that application of IAA alone and in combination with NAA @500ppm enhanced root length due to its higher ability of cell elongation.

Total weight of roots: Results regarding total weight of roots presented in Fig. 5 showed non-significant effect of treatment. Maximum total weight was recorded from offshoots treated with 500ppm NAA (607.4g) while minimum in control treatment. Our findings are supported by Al-Mana et al. (1996), they stated that total weight of newly developed adventitious roots was highest in NAA treatment.

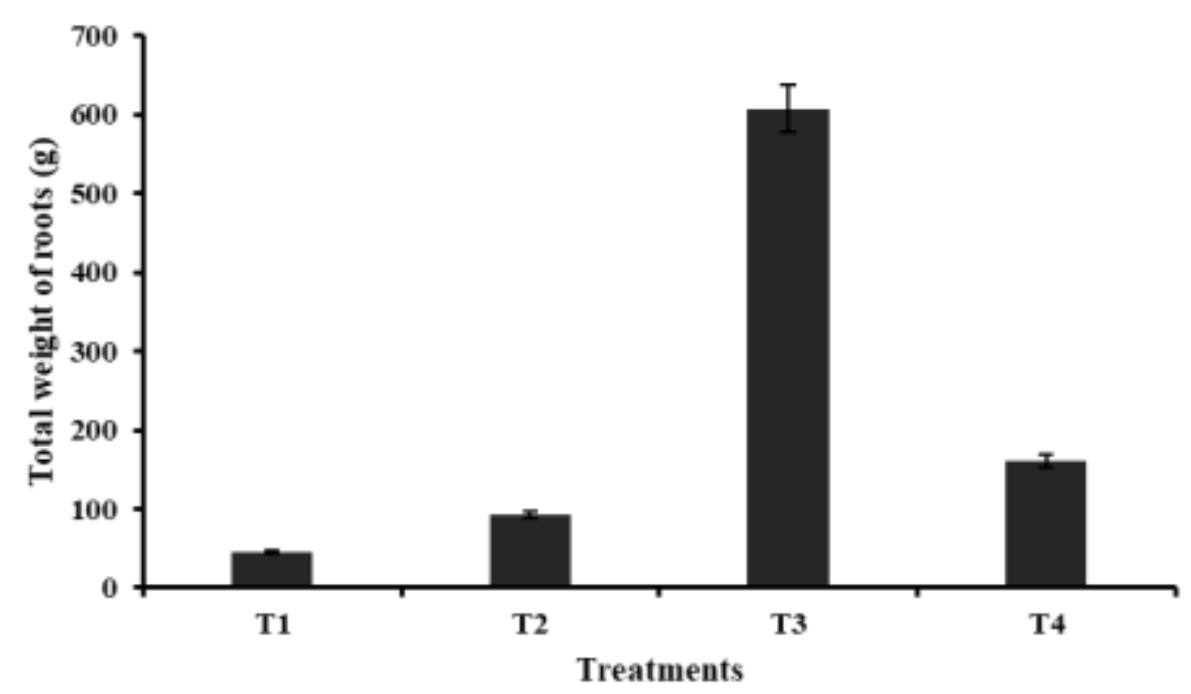

Fig. 5: Total weight of roots per offshoot as affected by rooting hormone application. $T_{1}=$ control, $T_{2}=$ 500ppm IAA, T $_{3}=500 \mathrm{ppm}$ NAA \& $\mathrm{T}_{4}=500 \mathrm{ppm}$ IAA+NAA.

Rooting percentage after 40days of treatment: Rooting percentage was calculated after 40days of treatment application and statistical analysis $(P \leq 0.05)$ showed that all treatments significantly improved the roots percentage of offshoots (Fig.6). Highest rooting percentage (24.5\%) was observed in offshoots treated with 500ppm NAA, followed by combine treatment of IAA and NAA $(8.83 \%)$ while minimum $(0 \%)$ was in control treatment. IAA alone or in combination with NAA gave low rooting percentage that may be due to effect of IAA oxidase. Our findings are in line with Rizk (2006) who stated that application of auxins significantly affected root initiation and rooting percentage of date palm offshoot

Final rooting percentage: Treatment application had significant effect on final rooting percentage of date palm. Highest final 
rooting percentage $(84.66 \%)$ was recorded in offshoots injected with NAA@500ppm while lowest $(7.66 \%)$ in control treatment (Figure $6)$. Results showed that application of rooting hormone caused food and early root initiation in aerial offshoots of date palm cv. Hillawi. Application of NAA was more favourable for root initiation. Our results are in line with AlMana et al. (1996). Maximum rooting percentage was obtained in NAA treatment. El-Kosary (2009) stated that application of rooting hormones significantly increased the rooting percentage in offshoots of date palm. Maximum rooting percentage was obtained by application of IBA followed by NAA and
IAA. Our results are supported by El-Hodairi et al. (1992) they observed application of NAA incised the rooting percentage (66\%).

\section{Conclusion}

According to above mentioned results it is concluded that application of rooting hormone by injecting in cotton plugs holes gave early and good root initiation, particularly NAA@500ppm is most constructive for rooting of aerial offshoots of date palm. This type of hormone application can be adopted commercially in date palm. In this way we can easily make use of those offshoots which are hard to root.

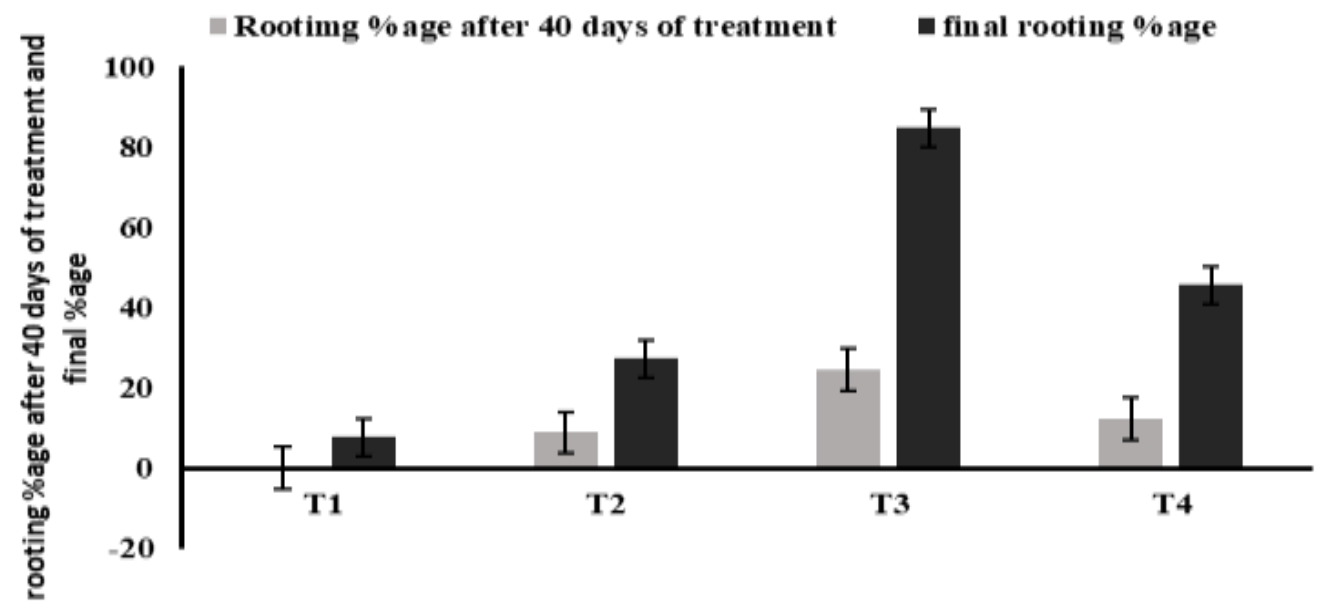

Fig. 6: rooting percentage after 40 days of treatment and final rooting percentage per offshoot as affected by rooting hormone application. $T_{1}=$ control, $T_{2}=500 \mathrm{ppm}$ IAA, $T_{3}=500 \mathrm{ppm} \mathrm{NAA} \mathrm{\&} T_{4}=500 \mathrm{ppm}$ IAA+NAA.

\section{References:}

Afzal, M., Khan, M. A., Pervez, M. A. and Ahmed, R. (2011). Root induction in the aerial offshoots of date palm (Phoenix dactylifera L.) Cultivar, HILLAWI. Pakistan Journal of Agricultural Sciences, 48:11-17.

Al-Farsi, M., Alasalvar, C., Morris, A., Baron M. and Shahidi F. (2005). Compositional and sensory characteristics of three native sun-dried dates (Phoenix dactylifera) varieties grown in Oman. Journal of Agriculture and Food Chemistry, 53:7586-7591.
Al-Mana, F.A., El-Hamday, M.A., Bacha, M.A. and Abdurrehman, A.O. (1996). Improving root development on ground and aerial date palm offshoots. Principals, 40:217-219

Al-Manzouri, H.S., Zaid, A. and Bouhouche, N. (2007). Morphological abnormalities in tissue cultured-derived date palm (Phoenix dactylifera L.). Procon. 3rd International Date Palm Conference, 329-335.

FAO, 2019. Food and agricultural organization, Available online with updates 
at http://www.fao.org/faostat/en/\#data/Q C

El-Hamady, M.M., Al-Mana, F.A. and Becre, M.A. (1992). Greenhouse rooting of date palm offshoots using an inverted mist system. Amals of Agriculture Sciences, Ain Shamans University, Cairo, 37:523-529.

El-Hodairi, M.H., El Fagih, A.S. and Amer, A.A. (1992). The effects of indole acetic acid (IAA), indole butyric acid (IBA) and naphthalene acetic acid on the growth of Taaghiyaat date palm (Phoenix dactylifera L). Acta Horticulture, 321: 326-333.

El-Kosary, S., Shaheen, M.A., Rizk, S.A.Y. and Abdel -Hameed. (2009). Rooting light weight offshoots of Zagloul date palm using hydroponics technique. Journal of Horticultural Sciences, 1:6878

Hartmann, H.T., Kester, D.E. and Geneve, R.L. (2011). Hartmann \& Kester's plant propagation principles and practices (No. 631.53 H2555p Ej. 1 025385). Prentice Hall.

Haseeb, G.M.M. El-Kosary, S.E., AbdElkareem, H.A. and Bakir, M.A.M. (2016). September. Induction of roots on young date palm offshoots using growth regulators injection. In VI International Symposium on Tropical and Subtropical Fruits, 1216: 115-126

Hunt, R.W., Chinnasamy, S., Bhatnagar, A. and Das, K.C. (2010). Effect of biochemical stimulants on biomass productivity and metabolite content of the microalga, Chlorella sorokiniana. Applied Biochemistry and Biotechnology, 8(162):2400-2414.

Husen, A. and Pal, M. (2006). Variation in shoot anatomy and rooting behaviour of stem cuttings in relation to age of donor plants in teak (Tectonagrandis Linn. f.). New Forests, 1(31):57-73.
Khan, M.A., Khalil, M.S. and Khatani, M.S. (1983). In vitro culture of different tissues of date palm offshoots. First international symposium on date palm in Saudi Arabia, Pp:52-157

Kheirallah, H.S.M. and Bader, S.M. (2007). Micro propagation of date palm (Phoenix dactylifera L.) var. Makhtoom through direct organogenesis. Eds. A Zack et al. Acta Horticulture, 736.

Krack, H., Marangoni, B. and Cristoferi, G. (1981). Hormonal changes during rooting of hardwood cuttings of grapevine rootstocks. American Journal of Ecology and Viticulture, 32:135-137.

Muhammed, S. (1978). Problems in date palm propagation. Indian Horticulture. 23:15-18

Mohammad, S., Shabana, H. R. and Mawlod, E.A. (1983). Evaluastion and identification of Iraqi date Cultivars. Fruit characters of 50 date cultivars. Date palm Journal, 2:27-55

Myhara, R.M., Karkala, J. and Taylor. M.S. (1999). The composition of maturing Omani dates. Journal of Science Food and Agriculture, 79:1345-1350

Pittenger, D.R., Downer, A.J. and Hodel, D.R. (2000). Palm root regeneration and its significance in transplanting. In: Ranney, T.G.(Ed.). Proceedings of the $11^{\text {th }}$ Conference of the Metropolitan Tree Improvement Alliance, 23-24 Aug.2000, Gesham OR. www.ces.ncsu.edu/fletcher/programs/nur sery/materia/materia11.

Purseglove, J.W. (1972). Tropical crop monocotyledonous long man group Ltd. London:430

Rashid., S. and Al-Obeed. (2005). Rooting of offshoots of four date palm cultivars by air layering method using polyethylene bags. Pakistan Journal of Biological Sciences, 7:978-981 
Raz, O. (1959). The use of polyethylene wrap in the rooting high date offshoots. Date Growers Inst. Rept. 36:19.

Rizk, S.A.Y. (2006). Some factors affecting on rooting ability of sew date palm offshoots in sewa oasis, Egypt. 2-Effect of offshoot weight and auxins application on rooting percentage and growth of sewy date palm. Minufiya Journal of Agriculture Research, 311007-1015.

Steel, F.G.D., Torrie, J.H. and Dickey, D.A. (1997). Principles and Procedures of Statistics; A Biometrical approach. 3rd ed. McMgraw Hill, New York

Vij, B.K., S.K. Karla and M.S. Bajwa. 1977. Studies on rooting of high offshoots in date palm. Punjab Horticulture Journal, 17:135-138

Yan, Y.H., Li, J.L. and Zhang, X.-Q. (2014). Effect of naphthalene acetic acid on adventitious root development and associated physiological changes in stem cutting of Hemarthriacompressa. PLoS ONE, no. 3. Article ID e90700,

Zirari, A. and LaazizaIchir, L. (2010). Effect of Exogenous Indole Butyric Acid (IBA) on Rooting and Leaf Growth of Small Date Palm Offshoots (Phoenix dactylifera L.) Derived from Adult Vitro plants of 'Najda' Cultivar. In IV International Date Palm Conference 882.p. 839- 844.

Publisher's note: JOARPS remains neutral with regard to jurisdictional claims in published maps and institutional affiliations.

This is an open access article distributed under the terms of the Creative Commons Attribution License (CC BY 4.0), which permits unrestricted use, distribution, and reproduction in any medium, provided the original author and

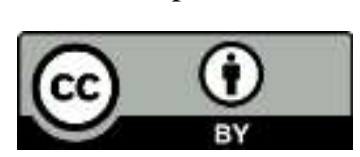

source are credited. To view a copy of this license, visit http://creativecommons.org/licenses/by/4.0/. 